\title{
ANALISIS KETERAMPILAN PROSES SAINS MAHASISWA PADA PRAKTIKUM DASAR-DASAR KIMIA ANALITIK
}

\author{
Analysis of Students' Science Process Skills in Practicum \\ on the Basics of Analytical Chemistry \\ Ayu Rahayu \\ Pendidikan Kimia, Universitas Sembilanbelas November Kolaka \\ email: yuayurahayu19@gmail.com
}

\begin{abstract}
Abstrak. Hasil belajar dalam pembelajaran kimia tidak hanya sebatas pada aspek kognitif tetapi harus melihat aspek afektif dan psikomotorik. Ketiga aspek tersebut dapat terukur dari kegiatan praktikum dan dapat mengetahui kemampuan keterampilan proses sains. Tujuan dari penelitian ini adalah untuk mengetahui dan mendeskripsikan keterampilan proses sains mahasiswa pada praktikum dasar-dasar kimia analitik. Penelitian ini menggunakan metode penelitian deskriptif yang dilakukam pada mahasiswa pendidikan kimia. Data hasil penelitian dianalisis secara kuantitatif dan kualitatif. Hasil menunjukkan bahwa presentase indikator keterampilan proses sains yang tertinggi adalah merencanakan percobaan yaitu $76.33 \%$ kategori baik sedangkan indikator terendah adalah menerapkan konsep yaitu $52.00 \%$ kategori cukup. Sehingga, secara keseluruhan keterampilan proses sains mahasiswa berdasarkan hasil observasi adalah $63.43 \%$ dengan kategori baik. Dengan demikian, dapat dinyatakan keterampilan proses sains mahasiswa pada praktikum dasar dasar kimia analitik adalah baik.
\end{abstract}

Kata kunci: keterampilan proses sains, praktikum, dasar kimia analitik

\begin{abstract}
Learning outcomes in learning chemistry are not only limited to cognitive aspects but also affective and psychomotor aspects. These three aspects can be measured by practical activities and they can determine the ability of science process skills. The purpose of this research was to find and describe the students' science process skills in practicum on the basics of analytical chemistry. This research used descriptive research method which was applied to chemistry education students. The research data were analyzed quantitatively and qualitatively. The results showed that the percentage of the highest science process skill indicators was planning an experiment that was $76.33 \%$ and classified as "good" category while the lowest indicator was applying the concept which was $52.00 \%$ classified as "sufficient"category. Therefero, overall students" science process skills based on observation was $63.43 \%$ and classified as "good" category. Thus, it could be stated that students' scientific process skills in practicum on the basics of analytical chemistry were good.
\end{abstract}

Keywords: science process skills, practicum, basics of analytical chemistry 


\section{PENDAHULUAN}

Penilaian hasil belajar biasanya hanya terfokus pada ranah kognitif saja karena dianggap berkaitan dengan kemampuan sesorang dalam menguasai isi bahan pengajaran. Namun, prestasi belajar dan hasil belajar dikatakan efektif dan efisien jika memenuhi tiga aspek yaitu aspek afektif berhubungan dengan pembangkitan minat, sikap/emosi, penghormatan (kepatuhan) terhadap nilai atau norma, aspek psikomotor berhubungan dengan pengajaran yang bersifat keterampilan atau yang menunjukkan kemampuan (skill) dan aspek kognitif berhubungan dengan pengenalan baru atau mengingat kembali (menghafal), memahami, mengaplikasikan, menganalisis, dan kemampuan mengevaluasi (Ghozali, 2017).

Salah satu langkah agar penilaian hasil belajar memuat semua aspek kognitif, afektif dan psikomotorik adalah menggunakan pendekatan saintifik yang merupakan kerangka ilmiah pembelajaran yang diterapkan pada kurikulum 2013. Pendekatan saintifik atau pendekatan ilmiah sangat penting dikembangkan agar mahasiswa yang merupakan calon pendidik dapat melakukan penelitian, mengajukan pertanyaan, mencapai pengetahuan ilmiah menggunakan pemikiran ilmiah, dan bahkan menggunakan pengetahuan tersebut untuk memecahkan masalah yang dihadapi dalam kehidupan sehari-hari. (Çakir \& Sarikaya, 2010).

Komponen-komponen dalam pendekatan saintifik seyogyanya dapat dimunculkan dalam setiap praktik pembelajaran, tetapi bukanlah sebuah siklus pembelajaran atau suatu model pembelajaran yang terdiri atas rangkaian tahap-tahap kegiatan yang disusun sedimikian rupa (Waseso, 2018). Pendekatan saintifik dapat diterapkan dengan cara interaksi langsung atau tidak langsung pada sumber belajar yang telah dirancang. Melalui pengalaman tersebut, seseorang dapat aktif menemukan sesuatu dan membangun pengetahuannya sendiri sesuai dengan teori belajar konstruktivisme. Konstruktivisme dapat memperhatikan pengetahuan prasyarat yang dimiliki, menggunakan pendekatan zona perkembangan terdekat, serta menggunakan pendekatan keterampilan proses sains, baik dasar maupun terintegrasi (Firdaus \& Mirawati, 2015).

Keterampilan proses sains dapat dikembangkan melalui kegiatan praktikum karena pembelajaran dengan praktikum dapat memberikan kesempatan kepada mahasiswa untuk mengalami atau melakukan sendiri serta dapat menentukan masalah, mengamati, menganalisis, berhipotesis, melaksanakan percobaan, menyimpulkan, dan menerapkan informasi yang mereka miliki sesuai dengan kebutuhan (Suryaningsih, 2017). Selain itu, Emda (2017) mengatakan bahwa dengan eksperimen atau praktikum dapat membangkitkan motivasi belajar, mendorong rasa ingin tahu sehingga prinsip tersebut akan menunjang mahasiswa untuk menemukan pengetahuan melalui eksplorasi. Kegiatan praktikum dilakukan disetiap jenjang pendidikan, khususnya di tingkat universitas yang bertujuan agar mahasiswa mendapat kesempatan untuk menguji dan mengaplikasikan teori atau penyelidikan dan pembuktian ilmiah matakuliah atau bagian matakuliah tertentu.

Salah satu matakuliah yang menerapkan kegiatan praktikum adalah dasar-dasar kimia analitik yang merupakan matakuliah dari jurusan pendidikan kimia. Matakuliah tersebut berbobot 3 sks dengan praktikum. Metode praktikum diberikan karena metode ini sangat efektif untuk membantu mahasiswa calon guru untuk mencari jawaban dengan usaha sendiri berdasarkan data yang benar (Wardani, 2011). Dasar-dasar kimia analitik mempelajari teori dan cara-cara melakukan analisis kimia terhadap suatu bahan atau zat 
kimia termasuk di dalamnya pemisahan, identifikasi dan penentuan komponen dalam sampel. Untuk itu dibutuhkan keterampilan proses sains dalam memahami atau mempelajari materi tersebut.

Berdasarkan observasi dan wawancara terhadap mahasiswa tentang kegiatan praktikum, terdapat temuan bahwa dosen belum pernah melakukan identifikasi secara menyeluruh terhadap indikator-indikator keterampilan proses sains yang muncul pada saat kegiatan praktikum berlangsung. Penilaian terhadap tugas, laporan praktikum, dan presentasi hasil kerja ilmiah telah dilakukan, namun belum mengidentifikasi kemampuan keterampilan proses yang dimiliki mahasiswa. Oleh karena itu perlu dilakukan penelitian tentang identifikasi kemampuan keterampilan proses sains mahasiswa pada praktikum dasar-dasar kimia analitik. Hasil penelitian ini diharapkan dapat memberikan gambaran tentang data awal untuk dilakukan penelitian lebih lanjut tentang keterampilan proses sains di perguruan tinggi. Sehingga Universitas Sembilanbelas November Kolaka, khususnya jurusan Pendidikan kimia, dapat melahirkan guru-guru sains dan sainstis yang memahami dan mengembangkan kerja ilmiah, terutama melalui pendekatan keterampilan proses sains.

\section{METODE PENELITIAN}

Subjek yang digunakan dalam penelitian ini adalah mahasiswa angkatan 2018 Universitas Sembilanbelas November Kolaka sebanyak 20 mahasiswa. Metode penelitian yang digunakan adalah penelitian deskriptif. Teknik pengumpulan data dilakukan dengan teknik observasi terstruktur, yaitu observasi yang telah dirancang secara sistematis dimana semua aktivitas observer dan materi observasi telah ditetapkan dan dibatasi dengan jelas dan tegas. Pada penelitian ini dilakukan observasi secara langsung terhadap mahasiswa selama kegiatan pembelajaran berlangsung dengan menggunakan pedoman observasi yang didalamnya memuat format penilaian dan kriteria-kriteria keterampilan proses sains mahasiswa yang akan diamati. Selanjutnya data pada lembar observasi tersebut digunakan sebagai data yang akan dianalisis secara kuantitatif dan kualitatif.

Adapun indikator keterampilan proses sains yang digunakan dalam penelitian ini adalah sebagai berikut (Rusman, 2012) :

Tabel 1. Indikator Keterampilan Proses Sains

\begin{tabular}{|c|c|c|}
\hline No & KPS & Indikator \\
\hline & Mengajukan & Bertanya apa, mengapa dan bagaimana \\
\hline 1 & Pertanyaan & Bertanya untuk meminta penjelasan \\
\hline 2 & Memprediksi & $\begin{array}{l}\text { Mengemukakan apa yang mungkin terjadi pada keadaan } \\
\text { yang belum diamati }\end{array}$ \\
\hline 3 & Mengamati & Menggunakan sebanyak mungkin indera \\
\hline 4 & Mengklasifikasi & $\begin{array}{l}\text { Mencatat setiap pengamatan secara terpisah } \\
\text { Membandingkan }\end{array}$ \\
\hline 5 & $\begin{array}{l}\text { Merancanakan } \\
\text { percobaan }\end{array}$ & $\begin{array}{l}\text { Menentukan alat/bahan/sumber yang akan digunakan } \\
\text { menentukan apa yang akan diukur,diamati dan dicatat } \\
\text { menentukan apa yang akan dilaksanakan berupa langkah } \\
\text { kerja }\end{array}$ \\
\hline 6 & $\begin{array}{l}\text { Menggunakan } \\
\text { alat/bahan }\end{array}$ & $\begin{array}{l}\text { Memakai alat/bahan } \\
\text { Mengetahui alasan mengapa menggunakan alat/bahan }\end{array}$ \\
\hline
\end{tabular}




\begin{tabular}{lll}
7 & $\begin{array}{l}\text { Menerapakan } \\
\text { Konsep } \\
8\end{array}$ & $\begin{array}{l}\text { Menggunakan konsep yang telah dipelajari dalam situasi } \\
\text { baru }\end{array}$ \\
9 & Benginterpretasi & $\begin{array}{l}\text { Menyimpulkan } \\
\text { Memberikan/ menggambarkan data empirirs dari hasil } \\
\text { percobaan atau pengamatan dengan grafik atau tabel atau } \\
\text { diagram } \\
\text { Menyusun dan menyampaikan laporan secara sistematis }\end{array}$ \\
\hline
\end{tabular}

\section{HASIL DAN PEMBAHASAN}

Berdasarkan hasil penelitian yang diperoleh dari kegiatan observasi selama kegiatan praktikum dasar dasar kimia analitik dengan 3 percobaan yaitu uji kation dan anion, iodimetri dan argentometri. Data disajikan dalam bentuk tabel dan diagram yang menunjukkan persen rata rata keterampilan proses sains mahasiswa secara keseluruhan, sebagai berikut:

Tabel 2. Hasil Observasi Keterampilan Proses Sains

\begin{tabular}{llccccc}
\hline No & $\begin{array}{c}\text { Keterampilan Proses } \\
\text { Sains }\end{array}$ & $\begin{array}{c}\text { Uji } \\
\text { Kation } \\
\text { Anion }\end{array}$ & $\begin{array}{c}\text { Iodim } \\
\text { etri }\end{array}$ & $\begin{array}{c}\text { Arge } \\
\text { ntom } \\
\text { etri }\end{array}$ & $\begin{array}{c}\text { Rata2 } \\
\%\end{array}$ & Kategori \\
\cline { 3 - 5 }$\%$ & $\begin{array}{c}\% \\
\%\end{array}$ & & \\
\hline 1 & Mengajukan Pertanyaan & 56.00 & 55.00 & 53.50 & 54.83 & Cukup \\
2 & Memprediksi & 55.00 & 52.00 & 51.00 & 52.67 & Cukup \\
3 & Mengamati & 75.00 & 74.00 & 74.00 & 74.33 & Baik \\
4 & Mengklasifikasi & 61.50 & 60.00 & 58.50 & 60.00 & Cukup \\
5 & Merancanakan percobaan & 77.00 & 75.00 & 77.00 & 76.33 & Baik \\
6 & Menggunakan alatbahan & 77.50 & 73.00 & 72.00 & 74.17 & Baik \\
7 & Menerapakan Konsep & 52.00 & 52.00 & 52.00 & 52.00 & Cukup \\
8 & Menginterpretasi & 54.00 & 54.00 & 54.00 & 54.00 & Cukup \\
9 & Berkomunikasi & 71.50 & 71.50 & 72.50 & 71.83 & Baik \\
\hline \multicolumn{7}{c}{ Rata-Rata Keseluruhan } \\
\hline
\end{tabular}

Hasil rekapitulasi data observasi keterampilan proses sains dalam bentuk diagram, sebagai berikut:

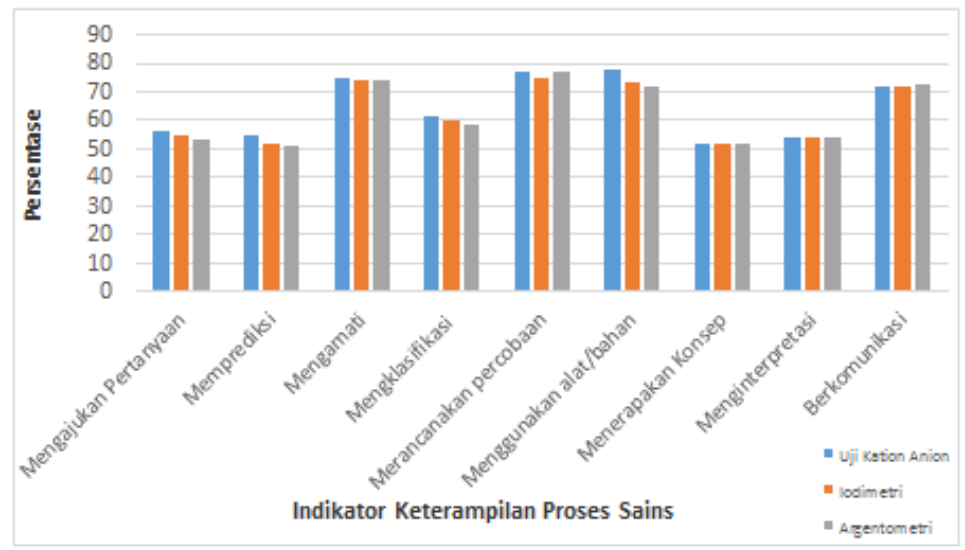

Gambar 1. Diagram Tingkat Penguasaan Keterampilan Proses Sains 
Keterampilan proses sains akan dideskripsikan lebih lanjut berdasarkan data diatas, sebagai berikut:

a. Keterampilan bertanya

Berdasarkan hasil analisis data pada Tabel 2 dan Gambar 1 menunjukkan bahwa keterampilan bertanya mahasiswa pada percobaan uji kation anion $56.00 \%$, percobaan iodimetri $55.00 \%$ dan percobaan argentometri 53.50\%. Sehingga dapat disimpulkan bahwa keterampilan bertanya pada praktikum dasar-dasar kimia analitik adalah $54.83 \%$ dengan kategori cukup.

Hasil observasi menunjukkan bahwa pertanyaan yang diajukan mahasiswa kurang berhubungan dengan orientasi masalah, dalam hal ini untuk menguji teori yang telah dimiliki sebelumnya, mereka cenderung menanyakan tentang teknis dalam melaksanakan percobaan, misalnya tentang alat dan bahan serta kepastian konsentrasi yang akan digunakan dalam praktikum.

Salah satu penyebab kemampuan bertanya mahasiswa kurang adalah tidak adanya rasa ingin tahu terhadap masalah atau percobaan yang akan diselesaikan, hal ini terlihat ketika diberikan stimulus diawal percobaan sebagai konsep dasar materi, sehingga nantinya mahasiswa akan mampu untuk membayangkan hal-hal seputar percobaan yang kemudian akan mereka pertanyakan namun kenyataannya mahasiswa kurang aktif merespon hal tersebut. Menurut Muntari et al. (2017) derajat keingintahuan seseorang dapat diindikasi dari kejelasan pertanyaan seseorang membuat dan mengajukan pertanyaan terhadap apa yang ingin diketahui dan apa yang telah dipahami. Keterampilan bertanya merupakan salah satu dari keterampilan proses sains yang wajib atau perlu dilatih dan dibiasakan karena ketika sesorang terbiasa bertanya maka nantinya akan memiliki kemampuan yang baik dan dapat meningkatakan kemampuan beripikir kritis (Nugraha et al., 2017).

b. Keterampilan memprediksi

Berdasarkan hasil analisis data pada Tabel 2 dan Gambar 1 menunjukkan bahwa keterampilan memprediksi mahasiswa pada percobaan uji kation anion $55.00 \%$, percobaan iodimetri $52.00 \%$ dan percobaan argentometri $51.00 \%$. Sehingga dapat disimpulkan bahwa keterampilan memprediksi pada praktikum dasar dasar kimia analitik adalah $52.67 \%$ dengan kategori cukup.

Hasil observasi menunjukkan bahwa hanya beberapa mahasiswa yang dapat memprediksi dengan benar mengenai percobaan yang akan dilakukan dalam praktikum, misalnya mereka dapat memprediksi perubahan yang terjadi pada uji kation anion dan memprediksi perubahan yang terjadi pada saat titik akhir titrasi yang sesuai dengan teori.

Hal yang dapat mempengaruhi sehingga hanya beberapa mahasiswa yang dapat memprediksi percobaan, yaitu disebabkan karena kegiatan praktium yang dilakukan di laboratorium ataupun kegiatan pembelajaran di kelas tidak dilatih atau terbiasa diberikan stimulus-stimulus untuk memprediksi kecenderungan suatu hal. Menurut beberapa mahasiswa, ketika akan melakukan kegiatan praktikum mereka hanya fokus mengkaji langkah-langkah yang akan dilakukan dan alat atau bahan yang akan digunakan.

Keterampilan memprediksi adalah menghubungkan fakta, konsep atau prinsip pengetahuan untuk membuat antisipasi atau ramalan tentang segala hal yang akan terjadi pada waktu mendatang (Dimyati, 2013). Sehingga, seharusnya sebagian besar mahasiswa dapat memprediksi kemungkinan kemungkinan yang dapat terjadi pada 
percobaan uji kation anion, iodimetri dan argentomentri karena mahasiswa telah mendapatkan teori sebelumnya.

c. Keterampilan mengamati

Berdasarkan hasil analisis data pada Tabel 2 dan Gambar 1 menunjukkan bahwa keterampilan mengamati mahasiswa pada percobaan uji kation anion $75.00 \%$, percobaan iodimetri $74.00 \%$ dan percobaan argentometri $74.00 \%$. Sehingga dapat disimpulkan bahwa keterampilan mengamati pada praktikum dasar dasar kimia analitik adalah $74.33 \%$ dengan kategori baik.

Mahasiswa berhati-hati dalam mereaksikan atau mencampurkan bahan kimia untuk mengamati perubahan yang terjadi pada uji kation dan anion, serta berhati-hati dalam melakukan titrasi agar titik ekuivalen dan titik akhir titrasi dapat diamati dengan baik pada uji coba iodimetri dan agentometri. Hal ini sejalan dengan pernyataan Muntari et al. (2017) bahwa mengamati adalah suatu kegiatan untuk mencari sebuah informasi yang membutuhkan atau melibatkan seluruh indra (membaca, mendengar, menyimak, melihat, menonton, dan sebagainya) dengan atau tanpa alat.

Hasil observasi dari sub indikator yang diamati pada keterampilan mengamati adalah menggunakan sebanyak mungkin indera, dapat disimpulkan bahwa kemampuan mahasiswa menggunakan indera pada percobaan uji kation dan anion, iodimetri dan argentometri adalah baik. Hal ini didukung karena mahasiswa melakukan pengamatan dengan baik dan benar menggunakan indera yang sesuai, sehingga proses pengamatan dapat berlangsung dengan lancar disetiap percobaan dan mahasiswa mencatat setiap hasil pengamatannya. Dengan metode observasi peserta didik menemukan fakta bahwa ada hubungan antara obyek yang dianalisis dengan materi pembelajaran yang digunakan sehingga proses pembelajaran memiliki kebermaknaan yang tinggi (Waseso, 2018).

d. Keterampilan mengklasifikasi

Berdasarkan hasil analisis data pada Tabel 2 dan Gambar 1 menunjukkan bahwa keterampilan mengklasifikasi mahasiswa pada percobaan uji kation anion $61.50 \%$, percobaan iodimetri $60.00 \%$ dan percobaan argentometri $58.50 \%$. Sehingga dapat disimpulkan bahwa keterampilan mengklasifikasi pada praktikum dasar dasar kimia analitik adalah $60.00 \%$ dengan kategori cukup.

Keterampilan mengklasifikasi adalah keterampilan untuk memilih berbagai objek peristiwa berdasarkan sifat-sifat khususnya, sehingga diperoleh golongan atau kelompok sejenis dari objek peristiwa yang dimaksud (Dimyati, 2013). Berdasarkan pernyataan tersebut indikator yang dipilih, dalam melakukan kegiatan mengklasifikasi yaitu mencatat hasil pengamatan secara terpisah dan membandingkan hasil pengamatan.

Berdasarkan keterangan yang diberikan observer, kegiatan mencatat hasil pengamatan dilakukan oleh sebagian besar mahasiswa karena mereka akan menggunakan data tersebut dalam pembuatan laporan sementara dan laporan akhir sedangkan kegiatan membandingkan hasil pengamatan dalam kategori rendah, hal ini disebabakan karena kurangnya motivasi atau kesadaran bertukar informasi dengan kelompok lain, seharusnya dapat dijadikan ajang diskusi untuk membandingkan atau menyesuaikan teori dengan hasil praktikum. Namun, berdasarkan pengamatan observer, bahwa mahasiswa hanya mengkaji hasil pengamatan dalam lingkup kelompoknya sendiri sehingga pemahaman mereka mengenai percobaan tersebut rendah.

e. Keterampilan merencanakan percobaan 
Berdasarkan hasil analisis data pada Tabel 2 dan Gambar 1 menunjukkan bahwa keterampilan merencanakan percobaan mahasiswa pada percobaan uji kation anion $77.00 \%$, percobaan iodimetri $75.00 \%$ dan percobaan argentometri $77.00 \%$. Sehingga dapat disimpulkan bahwa keterampilan merencanakan percobaan pada praktikum dasar dasar kimia analitik adalah $76.33 \%$ dengan kategori baik.

Hasil observasi menunjukkan bahwa keterampilan merencanakan percobaan baik dengan menggunakan beberapa sub indikator yaitu menentukan alat atau bahan, menentukan apa yang akan diamati, dan menentukan apa yang akan dikerjakan. Hal tersebut dikarenakan, mahasiswa sebelumnya telah memiliki pengalaman dalam melakukan praktikum baik di jenjang sekolah menengah ataupun praktikum yang telah dilakukan di semester sebelumnya, sehingga telah memiliki kemampuan mengenal alat dan bahan bahkan mengetahui fungsi penggunaannya. Selain itu, mahasiswa telah diberikan respon atau bimbingan sebelum melakukan percobaaan di laboratorium dan membuat jurnal praktikum yang didalamnya memuat tujuan dan langkah-langkah praktikum sehingga mahasiswa dapat menentukan apa yang akan diamati dan menentukan apa yang akan dikerjakan.

f. Keterampilan menggunakan alat dan bahan

Berdasarkan hasil analisis data pada Tabel 2 dan Gambar 1 menunjukkan bahwa keterampilan menggunakan alat dan bahan mahasiswa pada percobaan uji kation anion $77.50 \%$, percobaan iodimetri $73.00 \%$ dan percobaan argentometri $72.00 \%$. Sehingga dapat disimpulkan bahwa keterampilan menggunakan alat dan bahan pada praktikum dasar dasar kimia analitik adalah $74.17 \%$ dengan kategori baik.

Sub indikator keterampilan menggunakan alat yang diamati dalam praktikum ini adalah keterampilan menggunakan neraca analitik, menggunkan alat titrasi, menggunakan pengukur volume dan mengetahui alasan penggunaan alat dan bahan. Kesimpulan yang dapat diambil dari keterampilan menggunakan alat dan bahan berdasarkan indikator adalah sangat baik, meskipun masih ada faktor yang menjadi kekurangan, misalnya ketidakakuratan dalam penimbangan dan ketidaktelitian dalam menggunakan pengukur volume. Pengalaman sebelumnya mengenai penggunaan alat dan bahan dalam praktikum juga menjadikan mahasiswa dapat melakukan percobaan sebagaimana yang telah dikemukankan sebelumnya.

g. Keterampilan menerapkan konsep

Hasil analisis data pada Tabel 2 dan Gambar 1 menunjukkan bahwa keterampilan menerapkan konsep mahasiswa pada percobaan uji kation anion $52.00 \%$, percobaan iodimetri $52.00 \%$ dan percobaan argentometri $52.00 \%$. Sehingga dapat disimpulkan bahwa keterampilan menerapkan konsep pada praktikum dasar dasar kimia analitik adalah $52.00 \%$ dengan kategori cukup.

Hal ini terlihat ketika observer menanyakan penyebab perubahan dari pencampuran bahan kimia pada uji kation dan anion dan penyebab perubahan warna pada titrasi yang dilakukan pada percobaaan iodimetri dan argentometri. Hanya sebagaian mahasiswa yang bisa memberikan penjelasan meskipun penjelasan yang diberikan belum sempurna. Berdasarkan wawancara dengan beberapa mahasiswa, mereka mengakui bahwa dalam mempelajari konsep dasar-dasar analitik menggunakan metode menghafal untuk mengerjakan tes tertulis yang mengukur kemampuan ranah kognitif. 
Keterampilan menerapkan konsep merupakan salah satu keterampilan proses sains yang diperlu dilatihkan kepada mahasiswa agar konsep yang diperoleh tidak sekedar dihafal yang bersifat short term memory dan dapat diaplikasikan setiap saat. Proses berfikir tidak selalu di ukur dengan tes tertulis, apalagi dalam waktu yang sangat terbatas dengan lingkup konsep yang sangat luas. Proses berpikir dan potensi berfikir dapat diakses dengan cara lain seperti penilian kinerja dan portofolio (Asrul et al., 2014) h. Keterampilan menginterpretasi

Berdasarkan hasil analisis data pada Tabel 2 dan Gambar 1 menunjukkan bahwa keterampilan menginterpretasi mahasiswa pada percobaan uji kation anion $54.00 \%$, percobaan iodimetri $54.00 \%$ dan percobaan argentometri $54.00 \%$. Sehingga dapat disimpulkan bahwa keterampilan menginterpretasi pada praktikum dasar dasar kimia analitik adalah $54.00 \%$ dengan kategori cukup.

Keterampilan menginterprestasi berada pada kategori cukup. Berdasarkan wawancara dengan mahasiswa, mereka menganggap bahwa praktikum yang dilakukan hanya bersifat verifikasi yaitu hanya membuktikan kebenaran konsep yang mereka telah peroleh sehingga mereka hanya menyimpulkan hasil percobaan dalam laporan praktikum yang meraka buat setelahnya bukan menginterpretasi data secara langsung saat melakukan praktikum.

Keterampilan menginterpretasi perlu dilatihkan atau dibiasakan karena tidak akan cukup jika menggunakan penilaian tertulis. Misalnya dalam penilian kinerja yang mengukur proses berfikir yang lebih luas dimana mahasisiwa perlu mencatat hasil pengamatan secara terpisah, menghubungkan hasil pengamatan dan menemukan pola keteraturan untuk memperoleh suatu kesimpulan atau interpretasi data dari hasil pengamatan.

i. $\quad$ Keterampilan berkomunikasi

Berdasarkan hasil analisis data pada Tabel 2 dan Gambar 1 menunjukkan bahwa keterampilan berkomunikasi mahasiswa pada percobaan uji kation anion $71.50 \%$, percobaan iodimetri $71.50 \%$ dan percobaan argentometri $72.50 \%$. Sehingga dapat disimpulkan bahwa keterampilan berkomunikasi pada praktikum dasar dasar kimia analitik adalah $71.83 \%$ dengan kategori baik.

Cara berkomunikasi yang sering digunakan dalam ilmu pengetahuan adalah dengan menggunkan grafik, bagan peta, lambang, gambar, persamaan matematik. Cara berkomunikasi tersebut sama baiknya dengan kata-kata yang dituliskan atau dibicarakan (Dimyati, 2013). Dari pernyataan tersebut dapat dsimpulkan bahwa keterampilan berkomunikasi tidak hanya dilihat dari penyampaian secara lisan, sehingga dalam keterampilan berkomunikasi yang diamati adalah bagaimana kemampuan mahasiswa mengkomunikasikan hasil percobaan dalam bentuk grafik dan bentuk laporan.

Kategori baik, hal ini terlihat bahwa sebagian besar mahasiswa dapat menggambarkan data hasil percobaan pada laporan sementara dan dapat menyusun laporan akhir praktikum secara sistematis. Keterampilan berkomunikasi melalui laporan dapat melatih mahasiswa dalam mencari tahu kebenaran dengan teori yang ada dengan cara mencari teori yang berhubungan dengna masalah yang dikaji, selain itu menjadi wadah menyampaikan gagasan bagi mahasiswa yang memiliki keterbatas penyampaian secara lisan.

Berdasarkan hasil deskripsi keterampilan proses sains pada praktikum dasar dasar kimia analik dapat diketahui bahwa indikator tertinggi adalah merencanakan percobaan 
yaitu $76.33 \%$ kategori baik sedangkan indikator terendah adalah menerapkan konsep yaitu $52.00 \%$ kategori cukup. Penelitian ini sesuai dengan penelitian yang telah dilakukan oleh Ayd \& Education (2013) bahwa pembelajaran berbasis laboratorium merupakan bagian dari ilmu sains yang dapat mengukur keterampilan proses. Sedangkan penelitian lain yang dilakukan oleh Sumarti (2018) menyatakan bahwa hasil observasi keterampilan proses sains mendapat predikat baik sehingga dapat dinyatakan bahwa pelaksanaan pembelajaran kimia dengan praktikum berbantuan lembar kerja dapat mengasah keterampilan proses sains. Oleh karena itu, keterampilan proses sains pada praktikum dasar-dasar kimia analitik perlu diasah agar semua indikator-indikator keterampilan proses sains dapat dikuasai mahasiswa dengan baik.

\section{SIMPULAN}

Pada pelaksanaan praktikum dasar-dasar kimia analitik pada percobaan uji kation anion, iodimetri dan argentometri dapat disimpulkan bahwa keterampilan proses sains mahasiswa baik dengan persentase 63.43\%. Namun Presentase yang diperoleh masih menunjukkan angka kecil dalam kategori baik, hal ini disebabkan karena terdapat beberapa indikator keterampilan proses sains pada kategori rendah yaitu indikator mengajukan pertanyaan, memprediksi, mengklasifikasi, menerapkan konsep dan menginterpretasi. Sehingga dibutuhkan penyusunan penuntun praktikum yang dapat memunculkan dan melatih keterampilan proses sains mahasiswa secara keseluruhan ketika praktikum seperti penuntun praktikum berbasis inkuiri atau berbasis masalah pada praktikum dasar-dasar kimia analitik.

\section{DAFTAR RUJUKAN}

Asrul, Ananda, R., \& Rosinta. (2014). Evaluasi Pembajalaran. In Ciptapustaka Media.

Ayd, A., \& Education, S. T. (2013). International Journal of Education and Practice REPRESENTATION OF SCIENCE PROCESS SKILLS IN THE CHEMISTRY. 1(5), 51-63.

Çakir, N. K., \& Sarikaya, M. (2010). An evaluation of science process skills of the Science Teaching majors. Procedia - Social and Behavioral Sciences. https://doi.org/10.1016/j.sbspro.2010.12.370

Dimyati, M. dan. (2013). Model-model pengajaran dan pembelajaran. Teaching and Educations.

Emda, A. (2017). LABORATORIUM SEBAGAI SARANA PEMBELAJARAN KIMIA DALAM MENINGKATKAN PENGETAHUAN DAN KETRAMPILAN KERJA ILMIAH. Lantanida Journal. https://doi.org/10.22373/lj.v5i1.2061

Firdaus, L., \& Mirawati, B. (2015). Keterampilan proses sains dalam pembelajaran: suatu tinjauan teoretis. 1, 1-4.

Ghozali, I. (2017). Pendekatan Scientific Learning dalam Meningkatkan Belajar Siswa. Jurnal Pedagogik, 04(01), 1-13.

Muntari, I., Kadaritna, N., \& Sofia, E. (2017). Efektivitas LKS Pendekatan Saintifik Laju Reaksi dalam Meningkatkan KPS Berdasarkan Kemampuan Kognitif. Jurnal Pendidikan Dan Pembelajaran Kimia.

Nugraha, A. J., Suyitno, H., \& Susilaningsih, E. (2017). Analisis Kemampuan Berpikir Kritis Ditinjau dari Keterampilan Proses Sains dan Motivasi Belajar melalui Model PBL. Journal of Primary Education, 6(1), 35-43. 
Dalton : Jurnal Pendidikan Kimia dan Ilmu Kimia, Volume 3 Nomor 1, Mei 2020

Rusman. (2012). Model-model Pembelajaran Mengembangkan Profesionalisme Guru. In Jakarta: Rajawali Pers.

Sumarti, S. S. (2018). Meningkatkan Keterampilan Proses Sains Melalui Pembelajaran Koloid Dengan Lembar Kerja Praktikum Berorientasi Chemo-Entrepreneurship. Phenomenon: Jurnal Pendidikan MIPA, 8(2), 62. https://doi.org/10.21580/phen.2018.8.2.2499

Suryaningsih, Y. (2017). Pembelajaran Berbasis Praktikum Sebagai Sarana Siswa untuk Berlatih Menerapkan Keterampilan Proses Sains dalam Materi Biologi. Bio Educatio, 2(2), 279492.

Wardani, S. (2011). Pengembangan Keterampilan Proses Sains Dalam Pembelajaran Kromatografi Lapis Tipis Melalui Praktikum Skala Mikro. Jurnal Inovasi Pendidikan Kimia, 2(2), 317-322.

Waseso, H. P. (2018). Kurikulum 2013 Dalam Prespektif Teori Pembelajaran Konstruktivisme. Ta'lim. 